\title{
Glutamate Uptake Inhibition by Oxygen Free Radicals in Rat Cortical Astrocytes
}

\author{
Andrea Volterra, Davide Trotti, Cinzia Tromba, Stefano Floridi, and Giorgio Racagni \\ Center of Neuropharmacology, Institute of Pharmacological Sciences, University of Milan, 20133 Milan, Italy
}

Formation of reactive oxygen species and disfunction of the excitatory amino acid (EAA) system are thought to be key events in the development of neuronal injury in several acute and long-term neurodegenerative diseases. Recent evidence suggests that the two phenomena may be interdependent. The present study is aimed at exploring possible molecular mechanisms underlying oxygen radical-EAA interaction. Exposure of cortical astrocytic cultures to either xanthine + xanthine oxidase $(X / X O)$, a tree radical-generating system, or hydrogen peroxide $\left(\mathrm{H}_{2} \mathrm{O}_{2}\right)$ results in a marked decrease of high-affinity glutamate transport. Within $10 \mathrm{~min}$ of $X / X O$ application, uptake falls to $\approx 60 \%$ of its control value. In parallel no detectable release of lactate dehydrogenase occurs. $X / X O$ effect is abolished in the presence of a mixture of scavenger enzymes (superoxide dismutase + catalase) or by the disulfide-reducing agents glutathione and dithiothreitol (DTT), but not by lipophilic antioxidants or ascorbate. The time course of inhibition shows an almost linear decline of glutamate transport during cell exposure to free radicals, while upon their inactivation the decline stops but established inhibition persists for at least $1 \mathrm{hr}$. In this situation, application of DTT significantly restores transport function. These data suggest that free radicals inhibit glutamate uptake primarily by long-lasting oxidation of protein sulfhydryl (SH) groups. Chemical modifiers of free SH groups, such as $p$-chloromercuribenzoate and $\boldsymbol{N}$-ethylmaleimide, also induce uptake inhibition. $\mathrm{Na}^{+} / \mathrm{K}^{+}$ATPase is a known target of oxygen radicals and may be involved in glutamate uptake inhibition. Indeed, ouabain, a blocker of the pump, reduces uptake in astrocytes. However, its effect is largely additive with that of radicals. Electrophysiological recording of astrocytic resting conductance shows, in some cells, a $\mathrm{Ba}^{2+}$. insensitive, inward current in response to $\mathrm{H}_{2} \mathrm{O}_{2}$. However, in the majority of the cells, the oxidant has no effect on membrane current or voltage. In the same cells, application of glutamate in the presence of inhibitors of ionotropic EAA receptors elicits a large inward current representing electrogenic uptake. In six of seven tested cells, $\mathrm{H}_{2} \mathrm{O}_{2}$ significantly inhibited such current. These results indicate that inactivation of $\mathrm{Na}^{+} / \mathrm{K}+$ ATPase can be only part of the mechanism by which oxygen radicals inhibit glutamate uptak $\cap$ and that a direct action on glutamate transport is likely.

Received July 28, 1993; revised Oct. 12, 1993; accepted Oct. 26, 1993.

This project was partially supported by BIOMED 1, PL 921159 concerted action.

Correspondence should be addressed to Dr. Andrea Volterra, Center of Neuropharmacology, Institute of Pharmacological Sciences, University of Milan, Via Balzaretti, 9, 20133 Milan, Italy.

Copyright (C) 1994 Society for Neuroscience $0270-6474 / 94 / 142924-09 \$ 05.00 / 0$
In all, our data suggest that free radicals may induce extracellular accumulation of glutamate by reduction of glial uptake. In pathologies such as ischemia/reoxygenation or amyotrophic lateral sclerosis, where evidence for both oxidative stress and EAA uptake disfunction exists, this mechanism may link oxygen radical toxicity to excitotoxicity and represent an important step in the genesis of neurotoxic damage.

IKey words: oxygen free radicals, glutamate uptake, astrocytes, excitotoxicity, antioxidants, disulfide-reducing agents, protein thiol groups, redox modulation]

Oxygen-derived free radical species are formed during brain insults such as trauma and hypoxia/ischemia, particularly when followed by reoxygenation, and participate in the induction of neurotoxic injury (McCord, 1985; Braughler and Hall, 1989; Hall and Braughler, 1989; Siesjö et al., 1989). They have also been implicated in the toxicity associated with several longterm neurodegenerative disorders (Halliwell, 1992; Lees, 1993). In pathological conditions oxygen radical production is thought to overcome the endogenous protection system of scavenger enzymes and antioxidant molecules, either by "oxidative stress" (Halliwell, 1987) or "reductive stress" (Demopoulos et al., 1980). As a consequence, reactive species, including superoxide anion $\left(\mathrm{O}_{2}^{-}\right)$and, in particular, hydroxyl radical $\left(\mathrm{OH}^{*}\right)$, can attack cellular components like nucleic acids and nucleotides, protein $\mathrm{SH}$ (sulfhydryl) groups, or unsaturated fatty acid moieties of phospholipids (Slater, 1984). All these reactions are potentially toxic and may eventually lead to cell death. Membrane disruption and destabilization of $\mathrm{Ca}^{2+}$ homeostasis have been proposed as the major mechanisms by which free radicals induce neuronal damage (Boobis et al., 1989; Orrenius et al., 1989). However, the details of the mode of action of radicals, including the molecular targets and the sequence of events that lead to damage, remain still largely undefined. Another pathological event in common to ischemic and traumatic insult is extracellular accumulation of excitatory amino acids (EAA), which leads to excessive stimulation of glutamate receptors (Benveniste et al., 1984; Choi, 1988; Faden et al., 1989). Overfunctioning of such receptors, in particular of the NMDA type, is involved in the induction of irreversible neuronal damage (Rothman and Olney, 1987). Similar to oxidative stress, disfunction of the EAA system has been implicated in the pathogenesis of a number of long-term neurodegenerative disorders (Choi, 1992).

Several recent observations suggest that the mechanisms of oxygen free radical and EAA toxicity may be at least partially interdependent. In summary, (1) kainate-induced degeneration of cerebellar neurons in culture could be prevented by free radical scavengers (Dykens et al., 1987); (2) glutamate administration in a neuronal cell line led to glutathione (GSH) depletion 


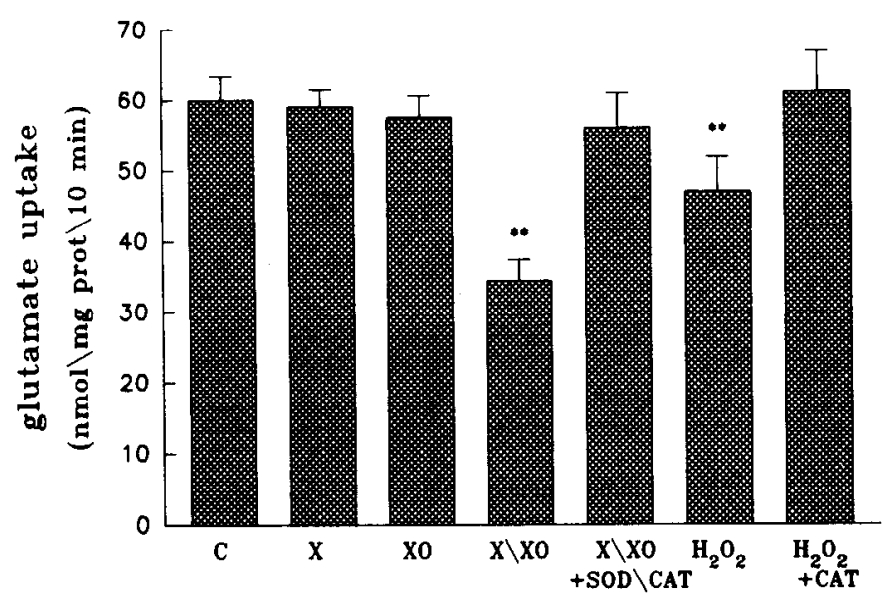

Figure 1. Glutamate uptake inhibition by free radical-generating systems and blockade of the effect in the presence of scavenger enzymes. ${ }^{3} \mathrm{H}$-glutamate uptake assay was run for $10 \mathrm{~min}$ in astrocytic cultures exposed to control conditions $(C)$ or to $\mathrm{X}(500 \mu \mathrm{M})$ or $\mathrm{XO}(50 \mathrm{mU} / \mathrm{ml})$ alone, $\mathrm{X} / \mathrm{XO}$ mixture without or with the scavenger cocktail SOD (90 $\mathrm{U} / \mathrm{ml})+\mathrm{CAT}(3000 \mathrm{U} / \mathrm{ml})$, or $\mathrm{H}_{2} \mathrm{O}_{2}(500 \mu \mathrm{M})$ without or with CAT. Each column of the histogram represents the mean \pm SD value of uptake obtained from 12-16 single determinations. One-way ANOVA reveals high statistical difference between treatments. In particular, as shown by the asterisks, $\mathrm{X} / \mathrm{XO}$ and $\mathrm{H}_{2} \mathrm{O}_{2}$ are significantly different from any other group. All the remaining treatments do not determine uptake values different from controls $\left({ }^{* *}, P<0.01\right.$, one-way ANOVA followed by the Tukcy method for multiple comparisons).

with peroxide formation (Murphy et al., 1989); (3) 21-aminosteroid compounds, inhibitors of lipid peroxidation, partially reduced excitotoxic neuronal death of cortical cell cultures (Monyer et al., 1990); (4) massive release of EAA in hippocampal slices subjected to "in vitro ischemia" was blocked by free radical scavengers and reproduced by free radical-generating systems (Pellegrini-Giampietro et al., 1990); and (5) oxidative inhibition of glutamine synthetase in parallel to free radical production was observed during early postischemic reperfusion in vivo (Oliver et al., 1990). On the other hand, $\mathrm{Ca}^{2+}$ influx through the NMDA receptors was reduced by free radicals acting at a redox modulatory site (Aizenman et al., 1990).

High-affinity glutamate reuptake systems, present in synaptic terminals and astrocytes, represent the major mechanism to control the extracellular levels of EAA and to keep them below neurotoxic values (McBean and Roberts, 1985). Defects in glutamate uptake function have been reported both in acute (Silverstein et al., 1986) and long-term (Rothstein et al., 1992) neurodegenerative pathologies associated with oxidative stress. Based on the hypothesis that an interaction between free radicals and EAA takes place during the devclopment of ncuronal damage, we became interested in exploring whether free radicals may act by inhibiting glutamate reuptake.

\section{Materials and Methods}

Astrocytic cell cultures. Primary astroglial cell cultures were obtained from the cerebral cortices of newborn rats by mechanical dissociation, plated, and grown in vitro for 2 weeks as previously described (Volterra et al., 1992). The cultures were then enriched (>95\%) in type 1 astrocytes following the procedure by McCarthy and de Vellis (1980), replated, and kept for 4-5 d until reaching monolayer confluence. For electrophysiological experiments cells were plated at low density and grown in vitro for only 3-5 d (i.e., before reaching confluence) to avoid formation of gap junctions between cells and conscquent spacc-clamp problems. These cultures contain more than one cellular type. For our studies we selected only cells with a quite uniform, flattened morphology (type 1-like astrocytes) that responded to the application of glutamate (30 $\mu \mathrm{M}$ ) with an inward current representing electrogenic uptake (see Results and Wyllie et al., 1991).

Glutamate uptake assay in astrocytes. Cortical astrocytes plated as a monolayer culture (200-300 $\mu \mathrm{g}$ protein $/ 35 \mathrm{~mm}$ Petri dish) were incubated in the presence of different agents at $25^{\circ} \mathrm{C}$ under circular shaking conditions for $10 \mathrm{~min}$ (unless otherwise specified) with oxygenated Krebs/ bicarbonate buffer containing (in $\mathrm{mM}$ ) $124 \mathrm{NaCl}, 4.6 \mathrm{KCl}, 1.2 \mathrm{CaCl}_{2}$, $1.3 \mathrm{MgCl}_{2} \times 6 \mathrm{H}_{2} \mathrm{O}, 0.416 \mathrm{KH}_{2} \mathrm{PO}_{4} \times 2 \mathrm{H}_{2} \mathrm{O}, 26.75 \mathrm{NaHCO}_{3}, 10$ glucose, adjusted to $\mathrm{pH} 7.4$, and $40 \mu \mathrm{M}{ }^{3} \mathrm{H}$-glutamate $(63.5 \mathrm{Ci} / \mathrm{mmol}$; NEN, Dreieich, Germany: isotopic dilution 1:25,000). Uptake assay was stopped by addition of ice-cold buffer with 100 -fold excess cold glutamate and cells scraped from the culture dishes with $\mathrm{NaOH}(0.2 \mathrm{~N})$ and counted by liquid scintillography for incorporated radioactivity. Protein content was measured in aliquots of the solubilized cells following the method of Lowry et al. (1951). ${ }^{3} \mathrm{H}$-glutamate concentration utilized is close to the $K_{\mathrm{m}}$ value of the high-affinity glutamate uptake in our astrocytic preparation (Volterra et al., 1992). Mean uptake values expressed as $\mathrm{nmol} / \mathrm{mg}$ protein $/ 10 \mathrm{~min}$ are reported in Figure 1. Elsewhere uptake is expressed as percentage of control, to facilitate comparisons among different experiments. In the experiments where uptake was measured after exposure to either xanthine + xanthine oxidase $(\mathrm{X} / \mathrm{XO})$ or $\mathrm{H}_{2} \mathrm{O}_{2}$ for $10 \mathrm{~min}$, the reaction generating the radicals was rapidly stopped by substituting the cell supernatant with one containing a cocktail of superoxide dismutase (SOD) $(90 \mathrm{U} / \mathrm{ml})+$ catalase (CAT) $(3000 \mathrm{U} / \mathrm{ml})$ and repeating the wash three times before adding Krebs buffer. To start glutamate uptake assay, ${ }^{3} \mathrm{H}$-glutamate was directly added together with the buffer at this point or after a further period of incubation (see legends for Figs. $2 B$, 4). In some of the experiments with antioxidants or SH reagents, different protocols were utilized: in most cases astrocytes were incubated for 20 min with any such agents and ${ }^{3} \mathrm{H}$-glutamate uptakc assay was run in the last $10 \mathrm{~min}$ of incubation. The irreversible SH chelator $p$-chloromercuribenzoate ( $\mathrm{pCMB}$ ) was added for $5 \mathrm{~min}$ to the cells and, after wash, uptake was tested in the next 5 min (see legends to Figs. 3, 5).

Electrophysiological patch-clamp recordings. Whole-cell recordings were performed with a List EPC 7 patch-clamp amplifier. Patch pipettes were made from borosilicate glass capillary tubes and had a resistance of 3-5 $\mathrm{M} \Omega$ when filled with the following (intracellular) solution (in $\mathrm{mM}$ ): $\mathrm{KCl}, 120 ; \mathrm{NaCl}, 5 ; \mathrm{CaCl}_{2}, 1 ; \mathrm{MgCl}_{2}, 7$; EGTA-KOH, 5; HEPES-KOH, 10; ATP(K), 5; pH 7.2. Cells in the bath were continuously superfused with a solution of the following composition (in $\mathrm{mM}$ ): $\mathrm{NaCl}, 140 ; \mathrm{KCl}$, 5.4; $\mathrm{CaCl}_{2}, 1.8 ; \mathrm{MgCl}_{2}, 1 ; \mathrm{HEPES}-\mathrm{NaOH}, 5 ; \mathrm{pH}$ 7.4. In some experiments $\mathrm{BaCl}_{2}(5 \mathrm{~mm})$ was added in order to block most of the $\mathrm{K}^{+}$conductances, giving rise to a large depolarization $(20-30 \mathrm{mV}$ over the resting potential; see also Brew and Attwell, 1987). Drugs were directly applied onto cells via a fast multiple-way microperfusion system. Resting potentials $\left(V_{m}\right)$ were generally around $-65 /-70 \mathrm{mV}$; the holding potential $\left(V_{h}\right)$ was kept close to $V_{\mathrm{m}}$. Experiments consisted of a continuous monitoring of the holding current and of the effects produced on its level by application of glutamate [ $30 \mu \mathrm{M}$ in the presence of $10 \mu \mathrm{M}$ 2-amino-5-phosphonovalerate (APV) $+100 \mu \mathrm{M}$ 6-cyano-7-nitroquinoxaline-2,3-dione (CNQX)] and/or $\mathrm{H}_{2} \mathrm{O}_{2}(1-5 \mathrm{mM})$, while changes in $V_{m}$ produced by these agents were revealed by rapid switching to the current-clamp mode. When the effect of $\mathrm{H}_{2} \mathrm{O}_{2}$ on glutamate uptake current was tested, a solution containing 1 or $5 \mathrm{mM} \mathrm{H}_{2} \mathrm{O}_{2}+30 \mu \mathrm{M}$ glutamate was prepared and perfused onto the cells on top of the glutamate response by switching the microperfusion line. Thin-layer chromatography of glutamatc present in such solution excluded oxidative damage to the transmitter by $\mathrm{H}_{2} \mathrm{O}_{2}$.

Lactate dehydrogenase activity assay. Lactate dehydrogenase (LDH) activity, as a marker of cell membrane disruption (Koh and Choi, 1987), was measured in samples $(0.15 \mathrm{ml})$ taken from the supernatant medium of astrocytic cultures exposed for different times to oxygen radicals. A diagnostic LDH kit from Sigma (procedure 228-UV) was utilized, with a calibration curve constructed from LDH standards (Sigma procedure 340-UV). Data are expressed as U/liter $/ \mathrm{min} / \mathrm{mg}$ protein, following the calculation protocol of the kit manual.

Measurement of the formation of thiobarbituric acid-reactive material. Formation of thiobarbituric acid-reactive material (TBAR), as an index of lipid peroxidation processes, was assessed by spectrophotometric measurement. After incubation (10-60 $\mathrm{min}$ ) of astrocytes $(1.2 \mathrm{mg}$ protcin) with $\mathrm{X} / \mathrm{XO}(50 \mathrm{mU} / \mathrm{ml})$ the reaction was stopped by the addition of $1.5 \mathrm{ml}$ ice-cold $\mathrm{HCl}(0.8 \mathrm{~N})$ containing $12.5 \%$ trichloroacetic acid 

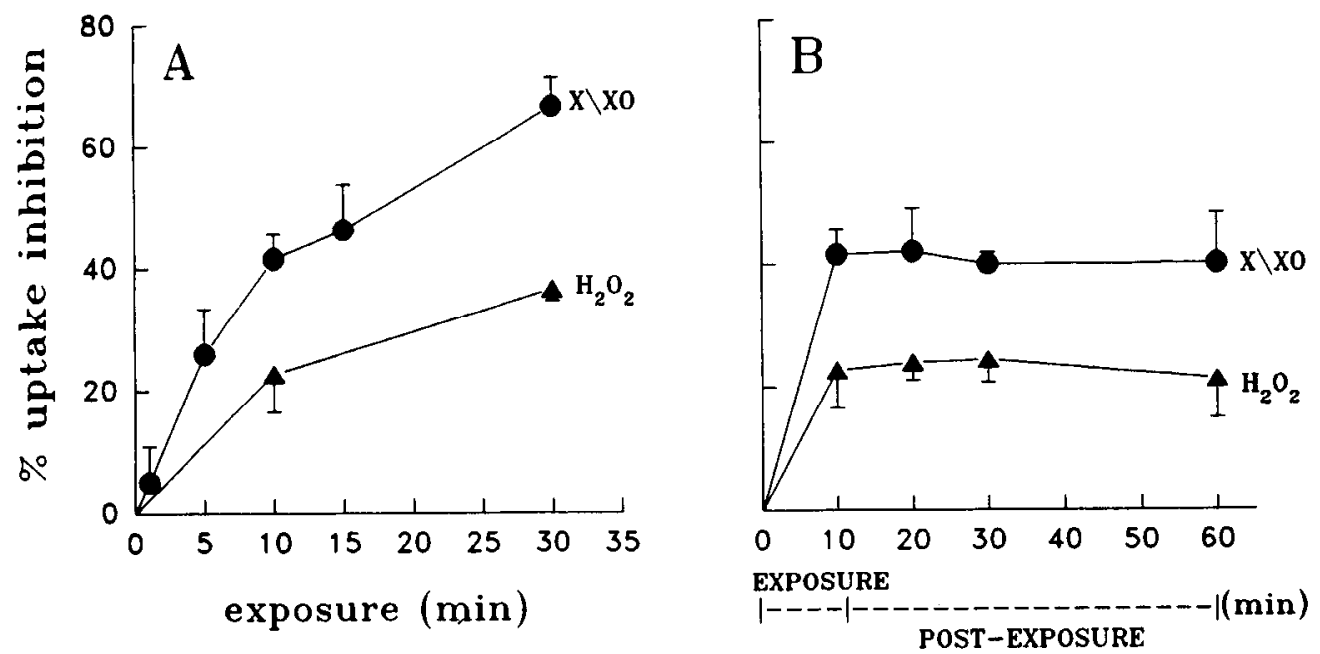

Figure 2. Glutamate uptake inhibition by free radicals is progressive during exposure $(A)$ and persistent after inactivation and removal of radicals (B). $A$, Time course study of ${ }^{3} \mathrm{H}$-glutamate uptake in astrocytic cultures during exposure to either $\mathrm{X}(500 \mu \mathrm{M}) / \mathrm{XO}(50 \mathrm{mU} / \mathrm{ml})(\bullet)$ or $\mathrm{H}_{2} \mathrm{O}_{2}(500$ $\mu \mathrm{M})(\Delta)$. For cach time point, uptake in the presence of free radicals was compared to uptake in control conditions and plotted as percentage of inhibition \pm SD. Data points represent the average of two or three experimental values in triplicate. $B$, Study of the duration of free radical-induced inhibition. Cells were first exposed to either $\mathrm{X} / \mathrm{XO}$ or $\mathrm{H}_{2} \mathrm{O}_{2}$ for $10 \mathrm{~min}$, and then washed three times with SOD/CAT-containing buffer and incubated in Krebs buffer for postexposure periods of variable duration. ${ }^{3} \mathrm{H}$-glutamate assay was performed in the last 10 min of each postexposure period and compared to uptake in control groups, which were initially exposed to Krebs buffer instead of radicals and then treated with an identical protocol. Data points are obtained from two or three different experiments in triplicate and calculated as above.

and the cells were scraped from Petri dishes. We then added $1.2 \mathrm{ml}$ of TBAR $(0.72 \%)$ to $300 \mu \mathrm{l}$ aliquots and the samples were boiled for 20 min. After cooling and centrifugation at $1500 \times \mathrm{g}$ for $15 \mathrm{~min}$, absorbance of supernatants at $532 \mathrm{~nm}$ was measured. Quantitation of TBAR was based on a standard curve constructed with malonyldialdehyde $(0.2-$ $30 \mathrm{~nm})$.

Materials. Xanthine oxidase (0.4-1.1 U/mg) was obtained from both Sigma and Fluka. The two enzyme preparations display different electrophoretic profiles: the Fluka preparation has a major protein band at $\approx 130 \mathrm{kDa}$, while the Sigma lacks such a band, showing a predominant band of $\approx 85 \mathrm{kDa}$. Some batches of Sigma XO at $50 \mathrm{mU} / \mathrm{ml}$ induced slight inhibition $(\approx 10 \%)$ of glutamate uptake in the absence of xanthine, which was blocked by aprotinin, a protease inhibitor. The Fluka enzyme did not modify basal uptake and was selected for the studies here reported. The other enzymes superoxide dismutase $(3250-3570 \mathrm{U} / \mathrm{mg})$ and catalase $(48,700 \mathrm{U} / \mathrm{mg})$, and reagents xanthine, reduced glutathione, DL-dithiothreitol (DTT), $p$-chloromercuribenzoic acid, $6 \alpha$-methylprednisolone-21-emisuccinate (MP), $\alpha$-tocopherol (VIT E; free and acetale ester), and ouabain were purchased from Sigma; $N$-ethylmaleimide (NEM), 5-5-dithio-bis-nitrobenzoic acid (DTNB), thiobarbituric acid, and malondialdehyde diethylacetate were from Aldrich; ascorbate was from Merck; and $\mathrm{H}_{2} \mathrm{O}_{2}$ was from Farmitalia-Carlo Erba. EAA receptor inhibitors APV and CNQX were from Tocris. Compound U74500A was kindly provided by Upjohn Co.

\section{Results}

The possible effect of oxygen free radicals on the high-affinity $\mathrm{Na}^{+} / \mathrm{K}^{+}$-dependent glutamate transport in glial cells was first explored by adding the free radical-generating system $\mathrm{X}$ (500 $\mu \mathrm{M}) / \mathrm{XO}(50 \mathrm{mU} / \mathrm{ml})$ to primary cultures of astrocytes from rat cerebral cortex, while running glutamate uptake assay (see Materials and Methods). We found that within $10 \mathrm{~min} \mathrm{X} / \mathrm{XO}$ induced $\approx 40 \%$ reduction of glutamate uptake (Fig. 1). Neither $X$ nor $\mathrm{XO}$ alone proved able to affect glutamate uptake, indicating that inhibition was due to the products of $\mathrm{X} / \mathrm{XO}$ reaction. Moreover, X/XO-induced inhibition could be almost completely prevented by addition of the cocktail of oxygen radical scavenger enzymes SOD $(90 \mathrm{U} / \mathrm{ml})$ and CAT $(3000 \mathrm{U} / \mathrm{ml}$; see Fig. 1). Neither SOD nor CAT modified glutamate uptake in control conditions and SOD alone was largely unable to prevent $\mathrm{X} / \mathrm{XO}$ effect (not shown). Analysis of the kinetic parametcrs of uptakc indicates that inhibition by $\mathrm{X} / \mathrm{XO}$ involves modification of both $K_{m}$ and $V_{\text {MAX }}$ values $\left(K_{m}:+22.8 \pm 5.6 \%\right.$ vs control; $p<0.05$, paired $t$ test; $V_{\mathrm{MAX}}:-37.3 \pm 12 \%$ vs control; $p<0.01$ ). We then tested the effect of $\mathrm{H}_{2} \mathrm{O}_{2}$, another important oxidant formed in living cells and a source of $\mathrm{OH}^{*}$ via iron catalysis (Siesjö et al., 1989). Similar to $\mathrm{X} / \mathrm{XO}, \mathrm{H}_{2} \mathrm{O}_{2}$ reduced glutamate uptake in a dose-dependent manner: we mostly utilized $500 \mu \mathrm{M} \mathrm{H}_{2} \mathrm{O}_{2}$, which inhibits uptake by $20 \%$. Inhibition by $\mathrm{H}_{2} \mathrm{O}_{2}$ was completely abolished in the presence of CAT (3000 U/ml; Fig. 1). The different efficacy of $\mathrm{X} / \mathrm{XO}$ and $\mathrm{H}_{2} \mathrm{O}_{2}$ in inhibiting glutamate uptake correlates with the respective potency as oxidants in our experimental medium. Reduction of glutamate uptake with either agents was observed in experiments on synaptosomes from rat cortex, suggesting that radicals may affect also neuronal highaffinity glutamate transport (data not shown).

We then studied the time course of the inhibitory action of oxygen radicals. In the presence of either $\mathrm{X} / \mathrm{XO}$ or $\mathrm{H}_{2} \mathrm{O}_{2}$, inhibition displayed a similar temporal pattern, appearing within a few minutes and then progressively increasing with time (up to $30 \mathrm{~min}$ of assay) without reaching a steady plateau level (Fig. $2 A$ ). Uptake function was then studied at various times after exposure of the cells to either $\mathrm{X} / \mathrm{XO}$ or $\mathrm{H}_{2} \mathrm{O}_{2}$ followed by inactivation and removal of the radicals (Fig. $2 B$ ). Inhibition outlasted the presence of radicals without significantly changing with time. The same level of inhibition induced by $10 \mathrm{~min}$ of exposure to $\mathrm{X} / \mathrm{XO}$ or $\mathrm{H}_{2} \mathrm{O}_{2}$ was observed $30 \mathrm{~min}$ and $1 \mathrm{hr}$ later. In one experiment with $\mathrm{X} / \mathrm{XO}$ it persisted for at least $4 \mathrm{hr}$ (not shown).

Free radicals are well-established toxic species for the cells. Therefore, uptake inhibition might simply reflect a general damaging action, such as disruption of the cell membrane integrity and loss of the ionic gradients. To investigate this possibility we measured the release of cytosolic LDH activity in the supernatant of astrocytic cultures after exposure to radicals as an index of membrane damage (Table 1). After $10 \mathrm{~min}$ in the 
Table 1. Extracellular LDH activity in astrocytic cultures after exposure to free radical-generating systems

\begin{tabular}{lcc} 
& $\begin{array}{c}\text { LDH activity } \\
(\mathrm{U} / \mathrm{L} / \mathrm{min} / \mathrm{mg} \\
\text { protein } \pm \mathrm{SD})\end{array}$ & $\begin{array}{c}\text { Number } \\
\text { of deter- } \\
\text { minations }\end{array}$ \\
\hline $10 \mathrm{~min}$ & & \\
$\mathrm{Control}$ & $7.7 \pm 2.4$ & 11 \\
$\mathrm{X} / \mathrm{XO}$ & $7.5 \pm 1.9$ & 8 \\
$\mathrm{H}_{2} \mathrm{O}_{2}$ & $6.1 \pm 0.8$ & 8 \\
$30 \mathrm{~min}$ & & \\
$\mathrm{Control}$ & $8.3 \pm 1.9$ & 10 \\
$\mathrm{X} / \mathrm{XO}$ & $24.5 \pm 2.9 *$ & 8 \\
$\mathrm{H}_{2} \mathrm{O}_{2}$ & $15.8 \pm 6.9$ & 6 \\
Triton X-100 $(0.1 \%)$ & $701.4 \pm 71.6$ & 16
\end{tabular}

Astrocytic cultures were incubated for 10 or $30 \mathrm{~min}$ in control conditions or in the presence of $\mathrm{X} / \mathrm{XO}(500 \mu \mathrm{M} / 50 \mathrm{mU} / \mathrm{ml})$ or $\mathrm{H}_{2} \mathrm{O}_{2}(500 \mu \mathrm{M})$. Cells' supernatants were then tested for $\mathrm{LDH}$ activity. Each determination was performed in duplicate and results of different experiments averaged together. In each experiment a separate group of cells was exposed for 10 min to the detergent Triton X-100 to acquire a comparative value of maximal cell damage. One-way ANOVA performed on control, $\mathrm{X} / \mathrm{XO}$, and $\mathrm{H}_{2} \mathrm{O}_{2}$ groups revealed significant treatment effect only at $30 \mathrm{~min}$. In particular, exposure of the cells to $\mathrm{X} / \mathrm{XO}$ induced a significantly higher $\mathrm{LDH}$ release with respect to control conditions, while $\mathrm{H}_{2} \mathrm{O}_{2}$ treatment was not reliably different from control.

** $P<0.01$, Tukey method for multiple comparisons.

presence of $\mathrm{H}_{2} \mathrm{O}_{2}$ or $\mathrm{X} / \mathrm{XO}$ at the same concentrations that significantly inhibit glutamate uptake, we were unable to detect any increase in the extracellular $\mathrm{LDH}$ with respect to controls. Treatment of the cells with the detergent Triton X-100 $(0.1 \%)$ gave an $\mathrm{LDH}$ value $\approx 100$-fold higher, which we considered the "maximal cell damage." Long exposures to free radicals, leading to high degrees of uptake inhibition (see Fig. $2 A$ ), correlated with little $\mathrm{LDH}$ release. After $30 \mathrm{~min}$ of incubation of the cells in control conditions, with $\mathrm{X} / \mathrm{XO}$, or with $\mathrm{H}_{2} \mathrm{O}_{2}, \mathrm{LDH}$ values were $1.18 \%, 3.49 \%$, and $2.25 \%$ of "maximal cell damage," respectively.

We then wanted to explore the molecular mechanism by which oxygen radicals inhibit glutamate uptake. As a first step, we evaluated the protective efficacy of various types of antioxidants. We first tested lipophilic molecules that preferentially insert into the membranes and are particularly suited for protection against lipid peroxidation chain reactions (Witting, 1980). These included the prototype lipophilic antioxidant VII E (20 or $200 \mu \mathrm{M}), \mathrm{MP}(100 \mu \mathrm{M})$, a corticosteroid exhibiting antioxidant properties at high concentrations (Demopoulos ct al., 1982), and $\mathrm{U} 74500 \mathrm{~A}(10 \mu \mathrm{M})$, a 21 -aminosteroid derivative that blocks lipid peroxidation reactions by chelating the iron catalyst (Braughler et al., 1987). Compounds were added to the cells 10 min prior to uptake assay to let them incorporate into the membranes, and also during the assay together with $\mathrm{X} / \mathrm{XO}$. All three lipophilic antioxidants, even if tested at high concentrations, were completely ineffective in preventing uptake inhibition (Fig. 3 ). In the same experimental conditions (10 min exposure to $\mathrm{X} / \mathrm{XO}$ ), we were unable to detect lipid peroxidative processes in astrocytes by monitoring the formation of TBAR products. A signal of peroxidation was observed only with a $1 \mathrm{hr}$ exposure. We then went on to test hydrophilic antioxidants, such as ascorbic acid (VIT C; $2 \mathrm{~mm}$ ) and GSH (4 mm). A dramatic difference in the effects of the two compounds was observed: while VIT C completely failed to prevent inhibition by $\mathrm{X} / \mathrm{XO}, \mathrm{GSH}$ blocked it by $>90 \%$ (Fig. 3). GSH is an endogenous antioxidant that can act either in conjunction with the enzyme glutathione

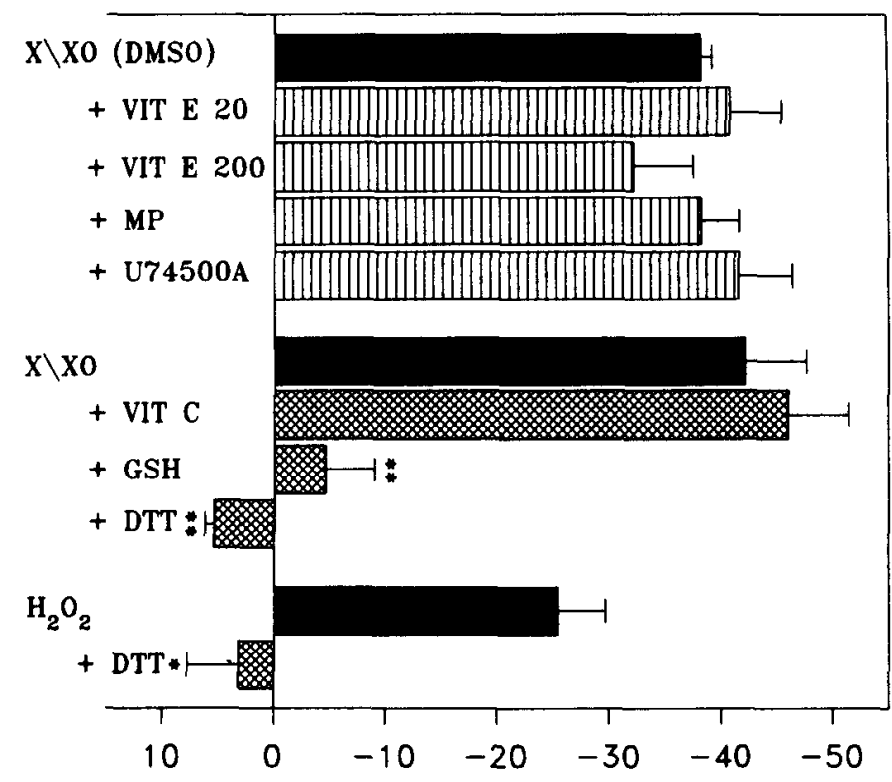

\section{GLUTAMATE UPTAKE (\% change vs control)}

Figure 3. Different effectiveness of various antioxidants in protecting glutamate uptake from free radical-induced inhibition. Astrocytic cultures were incubated for $20 \mathrm{~min}$ without (solid bars) or with antioxidants: lipophilic compounds (striped bars); hydrophilic compounds (crosshatched bars). In the first 10 min cells were exposed to buffer \pm antioxidants, while in the next $10 \mathrm{~min}$ free radical-generating systems $\mathrm{X} / \mathrm{XO}$ $(500 \mu \mathrm{M} / 50 \mathrm{mU} / \mathrm{ml})$ or $\mathrm{H}_{2} \mathrm{O}_{2}(500 \mu \mathrm{M}) \pm$ antioxidants were added and ${ }^{3} \mathrm{H}$-glutamate assay carried out. Lipophilic antioxidants were dissolved in dimethyl sulfoxide (DMSO) vehicle, in particular, VIT E $(20 \mu \mathrm{M})$, MP $(100 \mu \mathrm{M})$, and U74500A $(10 \mu \mathrm{M})$ in $1 \%$ DMSO (v/v), and VIT E $(200 \mu \mathrm{M})$ in $2 \%$ DMSO (giving a cloudy solution). Control uptake and uptake inhibition by free radicals in the absence of antioxidants were tested in DMSO for adequate comparison. In fact, $\mathrm{X} / \mathrm{XO}$ inhibition is slightly attenuated in DMSO (DMSO $1 \%$ : see first' bar; DMSO $2 \%$ : $-31.2 \pm 4.6 \%$, not shown), possibly due to antioxidant properties of the $\mathrm{S} \rightarrow \mathrm{O}$ group. Hydrophilic compounds VIT C ( $2 \mathrm{~mm})$, GSH (4 mM), and DTT $(2 \mathrm{mM})$ did not require vehicle and were compared to $\mathrm{X} / \mathrm{XO}$ or $\mathrm{H}_{2} \mathrm{O}_{2}$ in regular buffer. Bars show the percentage $\pm \mathrm{SD}$ of change induced in glutamate uptake by X/XO or $\mathrm{H}_{2} \mathrm{O}_{2}$ in the absence or presence of various antioxidants with respect to the corresponding control value, and are calculated from at least three different experiments in triplicate. Statistical evaluation of the protective effect of each antioxidant was performed by comparing the percentage of uptake inhibition induced in the same experiment by the free radical-generating system without and with that antioxidant. Asterisks indicate that only disulfidereducing agents modify inhibition by $\mathrm{X} / \mathrm{XO}$ or $\mathrm{H}_{2} \mathrm{O}_{2}$ in a statistically significant manner (**, $P<0.01$, and ${ }^{*}, P<0.05$, paired Student's $t$ test).

peroxidase as an $\mathrm{H}_{2} \mathrm{O}_{2}$ scavenger, or directly as a thiol substrate or disulfide-reducing agent (Meister and Anderson, 1983). To establish whether the $\mathrm{SH}$ redox properties of GSH were involved in the protection mechanism, we utilized another compound, DTT ( $2 \mathrm{~mm}$ ), which is a synthetic agent with selective disulfidereducing properties (Cleland, 1964). DTT not only completely protected glutamate uptake from $\mathrm{X} / \mathrm{XO}$ inhibition but also slightly enhanced it above control value. A cautionary point regarding the interpretation of the above results is that $\mathrm{XO}$ contains $\mathrm{SH}$ groups in its structure, whose redox state might affect enzyme function (Della Corte and Stirpe, 1972). Therefore, the capacity of GSH and DTT to protect uptake could be trivially explained by a reducing attack to XO resulting in decreased formation of free radicals. To rule out this possibility 


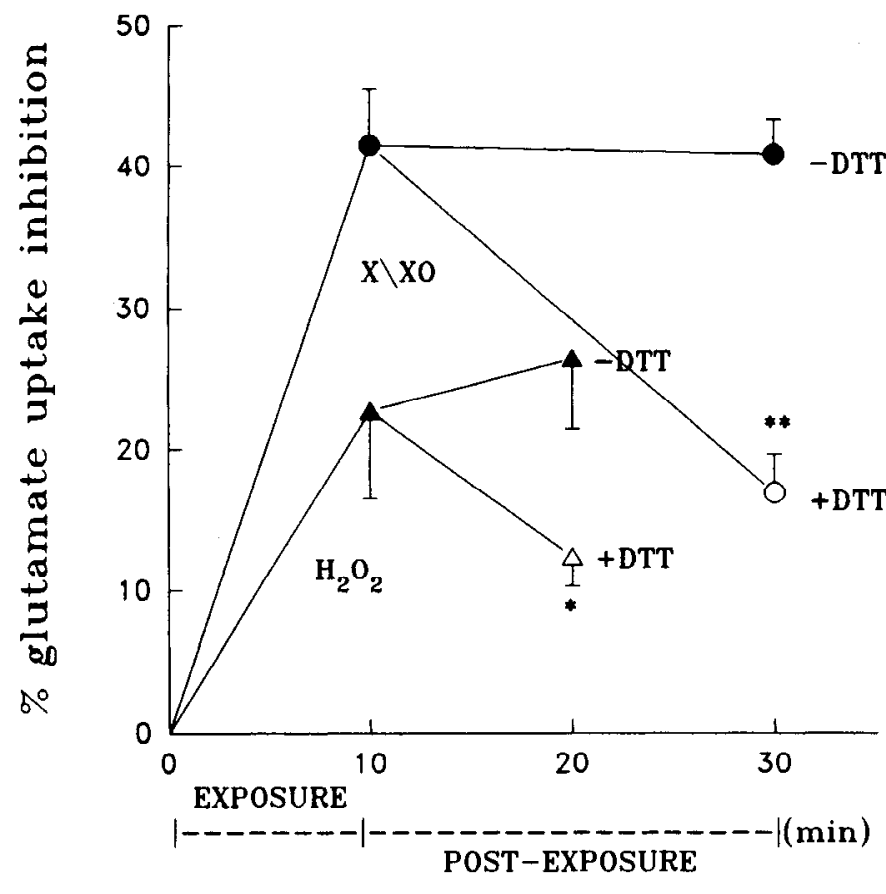

Figure 4. DTT largely reverses free radical-induced glutamate uptake inhibition. Astrocytic cultures were exposed for $10 \mathrm{~min}$ to either $\mathrm{X} / \mathrm{XO}$ $(500 \mu \mathrm{M} / 50 \mathrm{mU} / \mathrm{ml} ; \mathrm{O}$ and $\boldsymbol{O})$ or $\mathrm{H}_{2} \mathrm{O}_{2}(500 \mu \mathrm{M} ; \Delta$ and $\Delta)$. Removal of radicals was followed by a postcxposurc period ( $20 \mathrm{~min}$ for $\mathrm{X} / \mathrm{XO}$ group and $10 \mathrm{~min}$ for $\mathrm{H}_{2} \mathrm{O}_{2}$ group) in the absence $(\Delta, \bullet)$ or presence of $2 \mathrm{mM}$ DTT $(\triangle, O) .{ }^{3} \mathrm{H}$-glutamate uptake was tested in the last $10 \mathrm{~min}$ of the postexposure period and groups \pm DTT compared to controls (for details see Fig. $2 B$ legend). Data points represent the average \pm SD of three different experiments in triplicate. Groups incubated with DTT in the postexposure period show a statistically significant reduction of uptake inhibition with respect to groups without DTT, both in the case of $\mathrm{X} / \mathrm{XO}$ and of $\mathrm{H}_{2} \mathrm{O}_{2}$ exposure $\left(^{* *}, P<0.02\right.$, and ${ }^{*}, P<0.05$, respectively; paired Student's $t$ test).

we repeated the protection experiments using $\mathrm{H}_{2} \mathrm{O}_{2}$ instead of $\mathrm{X} / \mathrm{XO}$ and found that DTT also completely blocked the $\mathrm{H}_{2} \mathrm{O}_{2}$ effect (Fig. 3).

At this point we wanted to obtain further evidence that oxidation of thiol groups is involved in the inhibitory action of free radicals. Therefore, DTT was now administered after exposure of the cells to either $\mathrm{X} / \mathrm{XO}$ or $\mathrm{H}_{2} \mathrm{O}_{2}$, after uptake was inhibited and free radical-generating systems were no longer present. Within 10-20 min of incubation, DTT (2 mM) proved able to reverse at least $50-60 \%$ of the inhibition induced by either source of radicals (Fig. 4).

Finally, we exposed glial cells to different $\mathrm{SH}$ reagents in the absence of radicals (Fig. 5). Interestingly, control uptake was stimulated in the presence of the reducing agents GSH (4 mm) or DTT $(2 \mathrm{mM})(\approx+15 \%)$. On the contrary, a $30-40 \%$ reduction (without LDH release) was observed upon application of chemical SH modifiers such as pCMB $(10 \mu \mathrm{M})$ or NEM $(1 \mathrm{mM})$, while no relevant changes were seen with DTNB $(500 \mu \mathrm{M})$, a thiol oxidant that promotes formation of disulfide bridges between $\mathrm{SH}$ groups of vicinal cysteines.

As a next step, we asked which molecular substrates of free radical oxidation might be responsible for inhibition of glutamate uptake. $\Lambda \mathrm{t}$ first we focused on the $\mathrm{Na}^{+} / \mathrm{K}^{+}$ATPase pump for two reasons: (1) oxygen radicals have been reported to inhibit brain ATPase (Hexum and Fried, 1979), and (2) distinct purified isoforms of the protein contain reactive SH groups (Sweadner,

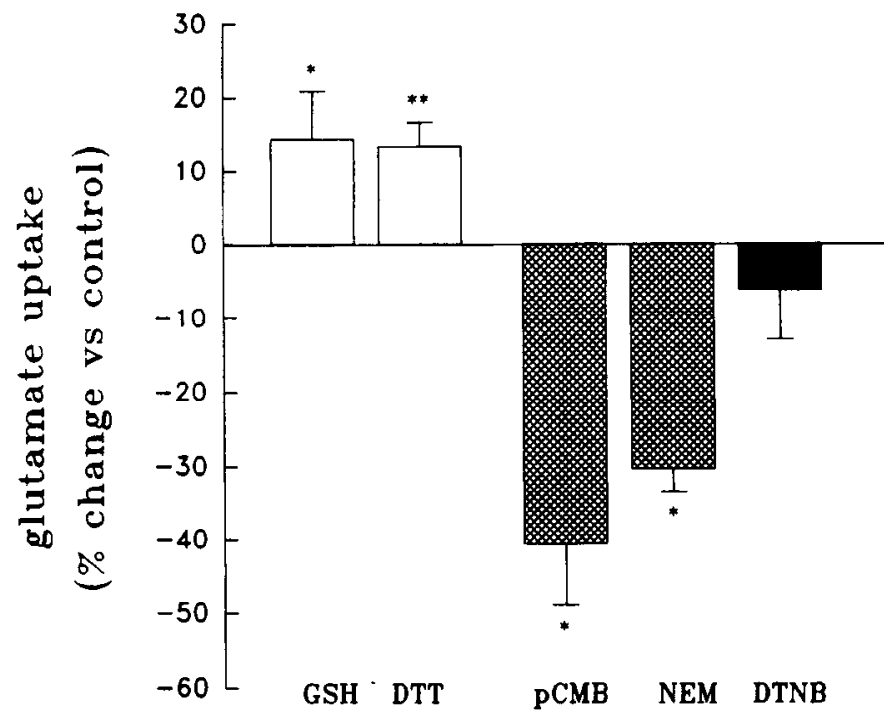

Figure 5. Glutamate uptake function is sensitive to SH reagents. Astrocytic cultures were exposed to distinct types of $\mathrm{SH}$ reagents: reducing agents GSH (4 mM) and DTT ( 2 mM) (open bars), SH modifiers pCMB $(10 \mu \mathrm{M})$ and NEM (1 mM) (crosshatched bars), and oxidant DTNB (500 $\mu_{\mathrm{M}}$ ) (solid bar). In all cases, except with pCMB, cells were incubated for 20 min with the $\mathrm{SH}$ reagent and uptake assay was run in the last 10 min by addition of ${ }^{3} \mathrm{H}$-glutamate to the medium. pCMB, dissolved in $1 \%$ DMSO, was applied to the cells for $5 \mathrm{~min}$ and then removed. After three washes, uptake was tested in the next $5 \mathrm{~min}$. In this case, controls were incubated with $1 \%$ DMSO for $5 \mathrm{~min}$, before wash and uptake assay. The effect of each SH reagent is expressed as percentage of variation $( \pm \mathrm{SD})$ with respect to uptake in the corresponding control conditions. Each value represents the average of at least three different experiments in triplicate. Asterisks indicate that all compounds, except DTNB, induce a statistically significant modification of glutamate uptake $\left({ }^{* *}, P<0.01\right.$, and ${ }^{*}, P<0.05$, respectively, vs control; two-tailed paired Student's $t$ test).

1979). To start we checked the relevance of ATPase inhibition on glutamate uptake function in astrocytes by measuring uptake in the presence of ouabain, a blocker of the pump. Indeed, incubation for $10 \mathrm{~min}$ with ouabain $(0.2-2 \mathrm{~mm})$ resulted in a dose-dependent inhibition of glutamate uptake (see Fig. 6 legend for quantitative data). The effect of ouabain on uptake saturated at $1 \mathrm{mM}$, a concentration reported to block glial ATPase completely (Sweadner, 1979). We then tested the effect of $\mathrm{H}_{2} \mathrm{O}_{2}$ on glutamate uptake in the presence of ouabain. Coadministration of $\mathrm{H}_{2} \mathrm{O}_{2}(0.5 \mathrm{mM})$ and $1 \mathrm{~mm}$ ouabain within $10 \mathrm{~min}$ led to $44.5 \%$ uptake inhibition, a significantly higher effect than those of either $\mathrm{H}_{2} \mathrm{O}_{2}$ or ouabain alone and amounting to $\approx 80 \%$ of their sum (Fig. 6). A time course study of uptake inhibition by ouabain revealed an increasing effectiveness of the ATPase blocker over time, similar to free radicals (Fig. 6; see also Fig. 2). However, at all times inhibition by ouabain was significantly lower than by $\mathrm{H}_{2} \mathrm{O}_{2}+$ ouabain. Moreover, the degree of additivity between $\mathrm{H}_{2} \mathrm{O}_{2}$ and ouabain effects did not change with time, being $86 \pm 7 \%$ at $5 \mathrm{~min}, 78 \pm 6 \%$ at $10 \mathrm{~min}$, and $81 \pm 9 \%$ at $20 \mathrm{~min}$.

We then decided to undertake an electrophysiological study to establish whether radicals act directly on the electrogenic glutamate uptake process. We first characterized the current related to astrocytic glutamate transport (see Brew and Attwell, 1987). Cells were whole-cell clamped at resting potential $(-65 /$ $-70 \mathrm{mV})$ and glutamate $(30 \mu \mathrm{M})$ was applied in the presence of inhibitors of ionotropic EAA receptors $(10 \mu \mathrm{M}$ APV +100 


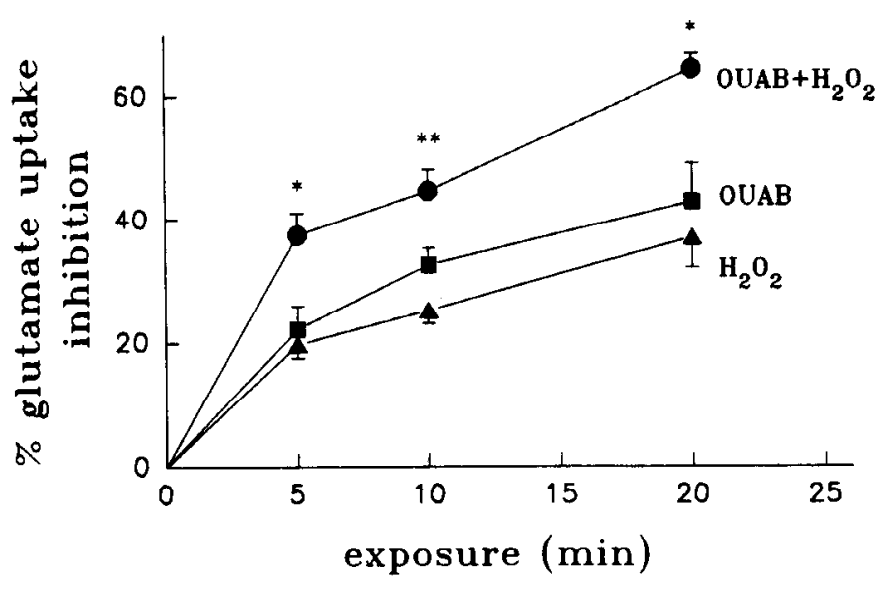

Figure 6. Time course of glutamate uptake inhibition induced by ouabain, $\mathrm{H}_{2} \mathrm{O}_{2}$, and their coadministration. Glutamate uptake was tested at different times $(5,10,20 \mathrm{~min})$ in the presence of ouabain $(1 \mathrm{~mm}$; $)$, $\mathrm{H}_{2} \mathrm{O}_{2}(500 \mu \mathrm{M} ; \boldsymbol{\Lambda})$, or ouabain $+\mathrm{H}_{2} \mathrm{O}_{2}$ (same concentrations; $\boldsymbol{\bullet}$ ). At 10 min, $0.2,1$, and 2 mM ouabain inhibited uptake by $24.3 \pm 4.9 \%(n=$ $3), 31.7 \pm 3.8 \%(n=4)$, and $31.2 \pm 7.5 \%(n=4)$, respectively, and 1 mM was selected as the saturating concentration. For each time point, uptake in the presence of the above agents was compared to uptake in control conditions and plotted as percentage of inhibition $( \pm S D)$. Data points represent the average of two or three experiments in triplicate. Statistical analysis reveals that coadministration of ouabain $+\mathrm{H}_{2} \mathrm{O}_{2}$ results in a significantly higher inhibition of uptake with respect to the exposure to either ouabain or $\mathrm{H}_{2} \mathrm{O}_{2}$ alone (**, $^{*} P<0.01$, and ${ }^{*}, P<$ 0.05 , one-way ANOVA followed by the Tukey method for multiple comparisons).

$\mu \mathrm{M}$ CNQX). Most of the cells responded to this treatment with an inward current, often $>100 \mathrm{pA}$, which showed clear voltage dependence, did not reverse at positive potentials, was apparently not accompanied by noise increase, and could be abolished by substitution of choline for sodium (Fig. $7 A$ ). Such features identify electrogenic glutamate uptake (see Wyllie et al., 1991). Only those cells displaying the type of current above described in response to glutamate were selected for further studies. In 8 of 19 such cells brief application of $\mathrm{H}_{2} \mathrm{O}_{2}(1-5 \mathrm{~mm})$ caused an inward current accompanied by slight membrane depolarization, which was insensitive to $5 \mathrm{mM} \mathrm{Ba}^{2+}$ and partially reversed upon washout of the compound (Fig. $7 B$; see legend for quantitative data). However, in the majority of the cells, $\mathrm{H}_{2} \mathrm{O}_{2}$ had no detectable effects on holding current or membrane potential (Fig. $7 C$, left). In these cells, we went on to test the effect of $\mathrm{H}_{2} \mathrm{O}_{2}$ on glutamate uptake current. Figure $7 \mathrm{C}$ (right) illustrates one such experiment representative of seven (see legend for quantitative data). At first, glutamate was applied to elicit inward uptake current, and then, when peak current was reached, $\mathrm{H}_{2} \mathrm{O}_{2}$ (1 mM, three cells; $5 \mathrm{~mm}$, four cells) was added together with glutamate (see Materials and Methods). In six cells glutamate current was substantially reduced by $\mathrm{H}_{2} \mathrm{O}_{2}$ within $30-40$ $\sec (-71.4 \pm 22.2 \%)$, while in one cell it was only slightly modified. When $\mathrm{H}_{2} \mathrm{O}_{2}$ was removed, glutamate current only partially recovered, while upon washout of glutamatc, $\mathrm{mcm}-$ brane current came back to its original holding level.

\section{Discussion}

The data here presented indicate that reactive oxygen species, generated by either $\mathrm{X} / \mathrm{XO}$ reaction or $\mathrm{H}_{2} \mathrm{O}_{2}$ administration, significantly reduce the capacity of high-affinity transport systems to take up and remove glutamate from the extracellular space. No release of cytosolic LDH from astrocytes was seen in parallel to uptake inhibition of $30-40 \%$, suggesting that the reduction observed in glutamate transport was not due primarily to cell damage, but to some more specific mechanism. As long as the cells were exposed to oxygen radicals, uptake inhibition increased progressively. When the reactive species were inactivated by addition of scavenger enzymes and removed from the cells, such increase stopped, but the established level of inhibition persisted for at least $1 \mathrm{hr}$. These observations suggest that free radicals act by inducing a long-lasting chemical modification of some substrate related to uptake function, possibly a protein or a lipid component of astrocytic membranes. In our studies three distinct lipophilic antioxidants, at concentrations that completely block lipid peroxidation in brain homogenates (Braughler et al., 1987), failed to prevent uptake inhibition by oxygen radicals. Moreover, no detectable peroxidation was observed in astrocytes in parallel to uptake inhibition with $\mathrm{X} / \mathrm{XO}$. On the contrary, the disulfide-reducing agents GSH and DTT completely abolished the effect of free radicals and DTT largely restored uptake function when applied after exposure to radicals. These data indicate that oxidation of protein thiol groups rather than lipid peroxidation is likely to represent the mechanism leading to glutamate uptake inhibition by free radicals. Since reversal of uptake inhibition with DTT is substantial but not complete, at present we cannot rule out other mechanisms in the action of radicals (Davies et al., 1987). However, the observation that, in the absence of radicals, GSH and DTT enhance while $\mathrm{pCMB}$ or NEM reduce control uptake reinforces the idea that sulfhydryl groups play a key role in controlling glutamate uptake function.

The opposing action exerted by oxidizing radical species and disulfide-reducing agents on glutamate uptake is reminiscent of the redox modulation of NMDA current (Aizenman et al., 1989, 1990). In that case, oxidation results in reduced $\mathrm{Ca}^{2+}$ entry through the NMDA channel. The functional consequences expected in the case of glutamate uptake are opposite: oxidation would increase the extracellular levels of glutamate, which in turn would enhance receptor activation. The overall outcome of these redox effects on glutamatergic transmission remains to be established with more integrated models.

Previous studies indicate that free radicals inhibit $\mathrm{Na}^{+} /$ $\mathrm{K}^{+}$ATPase in the brain (Hexum and Fried, 1979). Such inhibition would account for a disturbance of the physiological ion gradients and result in reduced driving force for glutamate uptake. Therefore, we investigated whether inactivation of $\mathrm{Na}^{+} /$ $\mathrm{K}+$ ATPase is the mechanism by which free radicals reduce glutamate transport. Application of $\mathrm{H}_{2} \mathrm{O}_{2}$ to astrocytes whole-cell clamped at resting potential induced a $\mathrm{Ba}^{2+}$-insensitive inward current accompanied by small membrane depolarization, which might reflect $\mathrm{Na}^{+} / \mathrm{K}^{+}$ATPase inhibition (see Fleming, 1980; Johnson et al., 1992). However, this effect was observed only in $40 \%$ of the cells, while in the remaining ones no appreciable change in holding current and membrane potential occurred with $\mathrm{H}_{2} \mathrm{O}_{2}$. Heterogeneity of ATPase isoforms present in glial cells might account for different cell sensitivity to $\mathrm{H}_{2} \mathrm{O}_{2}$ (McGrail et al., 1991). Biochemical experiments with ouabain indicate that pump inhibition progressively reduces glutamate uptake. However, in the presence of $1 \mathrm{~mm}$ ouabain, $\mathrm{H}_{2} \mathrm{O}_{2}$ further reduces uptake (by $\approx 80 \%$ of its expected effect). A possible explanation is that radicals and ouabain together block ATPase faster than ouabain alone, thereby affecting glutamate uptake in a more drastic way. Alternatively, the inhibitory mechanism of radicals may include a component other than ATPase inactivation. This 


\section{A $140 \mathrm{mM} \mathrm{NaCl}$ $A P V+C N Q X$}
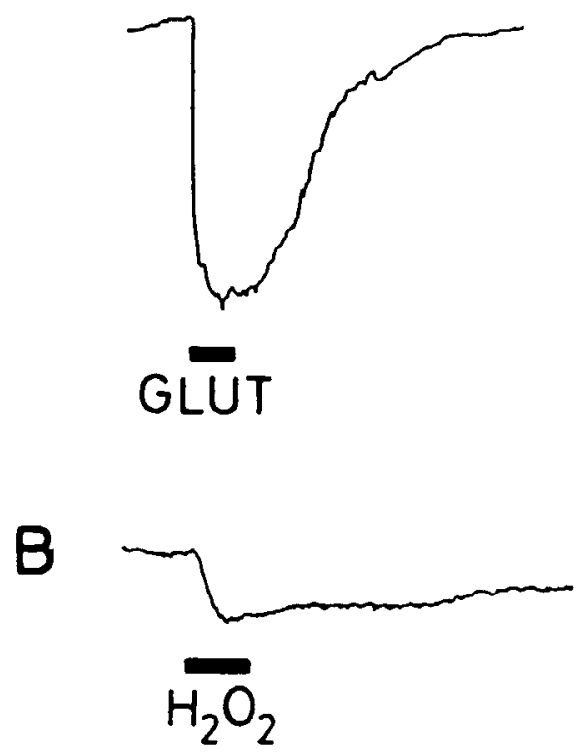

$0 \mathrm{NaCl}, 140 \mathrm{mM}$ Choline $A P V+C N Q X$

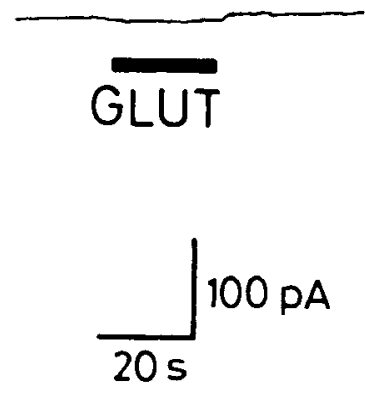

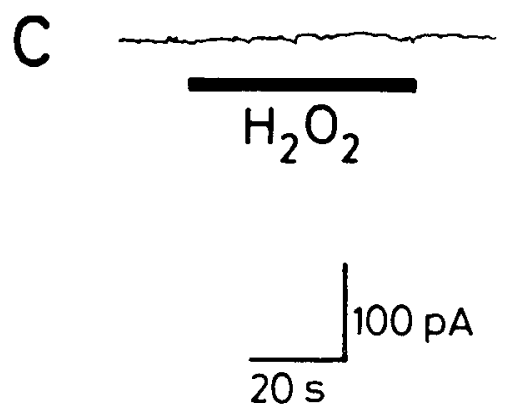

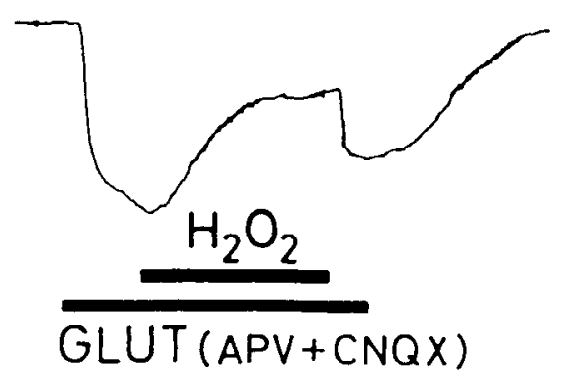

Figure 7. Electrophysiological analysis of $\mathrm{H}_{2} \mathrm{O}_{2}$ actions on holding current and glutamate uptake current in astrocytes. A: Left, Large inward current $(-300 \mathrm{pA})$ in an astrocyte whole-cell clamped at $-67 \mathrm{mV}\left(V_{h}=V_{m}\right)$ in response to brief application of glutamate (30 $\left.\mu \mathrm{M}\right)$ via fast microperfusion. The bathing solution is a normal saline containing $140 \mathrm{~mm} \mathrm{NaCl}+$ inhibitors of ionotropic glutamate receptors: APV (10 $\mu \mathrm{M}$ ) and CNQX $(100 \mu \mathrm{m})$. Right, Recording from the same cell $\approx 5$ min later, after switching bathing solution to a $\mathrm{Na}^{+}$-free medium, containing 140 $\mathrm{mM}$ choline $\mathrm{Cl}$. Longer application of glutamate is unable to elicit inward current in such medium. $B$, Effect of $\mathrm{H}_{2} \mathrm{O}_{2}$ perfusion $(5 \mathrm{mM}$ for $\approx 15 \mathrm{sec})$ onto a cell clamped at $-62 \mathrm{mV}$. Partial recovery $(\approx 45 \%)$ is observed upon washout of the compound. Such experiment was repeated in eight cells responding to glutamate as above and displaying an average $V_{m}$ of $-65.9 \pm 4 \mathrm{mV}$. Inward currents in response to $\mathrm{H}_{2} \mathrm{O}_{2}$ varied among different cells $(-62 \pm 48.3 \mathrm{pA})$, as did the degree of reversibility of the effect $(65 \pm 36 \%)$. In some cells $V_{m}$ at peak of $\mathrm{H}_{2} \mathrm{O}_{2}$ was read by rapid switch to the current-clamp mode and found depolarized by $3.4 \pm 3.6 \mathrm{mV}(\mathrm{n}=5)$. In thrce cells, where the experiment was performed in the presence of 5 $\mathrm{mM} \mathrm{Ba}^{2+}$, to abolish all astrocytic $\mathrm{K}^{+}$conductances (Newman, 1985), $\mathrm{H}_{2} \mathrm{O}_{2}$ still induced inward currents. The effect of DTT (2 mM) was also tested in seven cells: in four, DTT did not modify holding current; in two, elicited a small outward current ( $34 \pm 6$ pA); in one, a small inward current $(-15 \mathrm{pA})$ (not shown in the figure). $C$ : Left, Absence of effect of $\mathrm{H}_{2} \mathrm{O}_{2}$ on astrocytic holding current in another cell. $V_{m}$ is $-68 \mathrm{mV}$. Note that application of $\mathrm{H}_{2} \mathrm{O}_{2}$ is significantly longer than in $B$. Similar result was obtained in 11 cells, which did not display gross differences from the ones in $B$ with respect to morphology, $V_{m}$, or entity of glutamate uptake current. Right, In the same cell, $\approx 3$ min after test on holding current, $\mathrm{H}_{2} \mathrm{O}_{2}(5$ $\mathrm{mm}$ ) inhibits glutamate uptake current. Response to glutamate (+ APV/CNQX) in this cell is $-195 \mathrm{pA}$ at peak before $\mathrm{H}_{2} \mathrm{O}_{2},-70 \mathrm{pA}$ after 40 sec in the presence of $\mathrm{H}_{2} \mathrm{O}_{2}$, and $-135 \mathrm{pA}$ at peak after $\mathrm{H}_{2} \mathrm{O}_{2}$. On average, in six experiments $\mathrm{H}_{2} \mathrm{O}_{2}$ reduced glutamate uptake current from $-118 \pm$ $111 \mathrm{pA}$ to $-42 \pm 54 \mathrm{pA}$, with a statistically significant effect $(P<0.05$, two-tailed paired Student's $t$ test $)$.

latter possibility is supported by the observation that $\mathrm{H}_{2} \mathrm{O}_{2}$, in most of the cells where it does not modify membrane current, significantly inhibits glutamate uptake current, suggesting that free radicals directly interfere with the glutamate transport process. At present, no information exists about chemical reactivity of glutamate transporters to oxygen radicals. However, a report that $\mathrm{pCMB}$ affects $\mathrm{Na}^{+}$-dependent glutamate binding to synaptic membranes (thought to represent binding to the trans- porter) suggests that glutamate transporters might contain functionally relevant SH groups (Ogita and Yoneda, 1986). Indeed, a recently cloned glial glutamate transporter carries both a single cysteine in its major external loop and two close cysteins in a membrane-spanning domain (Pines et al., 1992). Therefore, it will be of great interest to see whether free radicals may react at those sites with the transporter protein resulting in functional inhibition of the uptake process. 
Uncontrolled formation of oxygen radicals as well as abnormal elevation of the extracellular levels of EAA have been shown to occur as a consequence of traumatic or ischemic insults (see Siesjö et al., 1989). Glutamate uptake inhibition by free radicals could be an important mechanism linking the two phenomena and possibly contributing to their neurotoxic consequences. At present the basic mechanisms leading to pathological EAA accumulation in ischemia/reoxygenation are still controversial. Both $\mathrm{Ca}^{2+}$-dependent exocytotic release of glutamate (Bosley et al., 1983; Drejer et al., 1985) and $\mathrm{Ca}^{2+}$-independent phenomena, such as impaired or reversed uptake function (Ikeda et al, 1989; Katayama et al., 1991; Rubio et al., 1991), have been implicated. Interestingly, Pellegrini-Giampietro et al. (1990) found that "in vitro ischemia" in hippocampal slices leads to massive $\mathrm{Ca}^{2+}$-independent release of EAA that is blocked by radical scavengers and reproduced by radical-generating systems. Our present finding that oxygen radicals inhibit glutamate uptake could well explain such phenomenon.

To our knowledge, only a few studies directly checked neurotransmitter reuptake function under hypoxic/ischemic conditions. All of them reported reduced glutamate or D-aspartate uptake (Weinberger and Cohen, 1982; Hauptman et al., 1984; Silverstein et al., 1986; Swanson, 1992). Moreover, even during postischemic reflow, when normal metabolic and ion conditions are reestablished, glutamate uptake did not promptly recover (Hauptman et al., 1984; Silverstein et al., 1986). In particular, Silverstein et al. (1986) found normal uptake $24 \mathrm{hr}$ but not 1 $\mathrm{hr}$ after transient ischemia and concluded that reduced uptake was due to some specific persistent inhibitory mechanism. They implicated arachidonic acid, which is massively released during ischemia and potently inhibits glutamate uptake in vitro (Barbour et al., 1989; Volterra et al., 1992). Based on the present results, formation of oxygen free radicals could also take part in the process. In fact, the arachidonate effect is strictly dependent on the presence of the free fatty acid and is mostly reversed upon its removal (Volterra et al., 1992). In many brain areas this occurs within the first 15-30 min of reperfusion (Yoshida et al., 1982). On the contrary, the effect of radicals presented here is independent of their lifetime and, in our in vitro conditions, lasts at least $1 \mathrm{hr}$ after their neutralization. Interestingly, a slow, progressive wave of extracellular accumulation of EAA, which develops during postischemic reflow, has been observed by some authors (e.g., Andinè et al., 1991). At parallel times, hyperactivity of hippocampal glutamatergic fibers preceding functional death was reported (Andinè et al., 1988; Urban et al., 1989). Long-lasting inhibition of glutamate uptake induced by free radicals might play a role in the development of this late component of EAA accumulation and damage.

Amyotrophic lateral sclcrosis (ALS) is another degencrative neurologic disorder where disturbance of glutamate uptake function as well as oxidative stress might play a central role. Thus, recent data show that glutamate uptake is decreased selectively in the brain and spinal cord areas associated with motor neuron degeneration (Rothstein et al., 1992). Moreover, genetic linkage between a familial variant of ALS and defects in the gene encoding for a cytosolic form of the SOD enzyme (SOD-1) was recently described (Rosen et al., 1993). In view of a better understanding of the mechanisms leading to neurotoxicity in this disease, it will be of importance to investigate whether oxidative stress and excitotoxicity are linked by free radical-induced inhibition of glutamate uptake.

In conclusion, we have shown that glial glutamate transport is a functional target in the action of reactive oxygen species. This evidence indicates an additional mechanism for oxygen radical toxicity and reinforces the concept that free radicals and EAA may cooperate in the genesis of neurotoxic injury. Protein oxidation more than lipid peroxidation seems relevant in this case. This observation may prove important for the antioxidant therapeutic approach against excitotoxic neuronal damage. In fact, while lipophilic antioxidants already demonstrated an ability to attenuate excitotoxicity (Miyamoto et al., 1989; Monyer et al., 1990), new agents able not only to interfere with lipid peroxidation reactions but also to preserve or restore the physiological redox state of proteins could result in a more complete neuroprotection.

\section{References}

Aizenman E, Lipton SA, Loring RH (1989) Selective modulation of NMDA responses by reduction and oxidation. Neuron 2:257-263.

Aizenman E, Hartnett KA, Reynolds IJ (1990) Oxygen free radicals rcgulate NMDA reccptor function via a rcdox modulatory site. Neuron 5:841-846.

Andinè P, Jacobson I, Hagberg H (1988) Calcium uptake evoked by electrical stimulation is enhanced postischemically and precedes delayed neuronal death in CAl of rat hippocampus: involvement of $N$-methyl-D-aspartate receptors. J Cereb Blood Flow Metab 8:799807.

Andinè P, Orwar O, Jacobson I, Sandberg M, Hagberg H (1991) Changes in extracellular amino acids and spontaneous neuronal activity during ischemia and extended reflow in the CAI of the rat hippocampus. J Neurochem 57:222-229.

Barbour B, Szatkowski M, Ingledew N, Attwell D (1989) Arachidonic acid induces a prolonged inhibition of glutamate uptake into glial cells. Nature 342:918-920.

Benveniste H, Drejer J, Schousboe A, Diemer NH (1984) Elevation of the extracellular concentrations of glutamate and aspartate in rat hippocampus during transient cerebral ischemia monitored by intracerebral microdialysis. J Neurochem 43:1369-1374.

Boobis AR, Fawthrop DJ, Davies DS (1989) Mechanisms of cell death. Trends Pharmacol Sci 10:275-280.

Bosley TM, Woodhams PL, Gordon RD, Balàzs R (1983) Effects of anoxia on the stimulated release of amino acid neurotransmitters in the cerebellum in vitro. J Neurochem 40:189-201.

Braughler JM, Hall ED (1989) Central nervous system trauma and stroke. I. Biochemical considerations for oxygen radical formation and lipid peroxidation. Free Radical Biol Med 6:289-301.

Braughler JM, Pregenzer JF, Chase RL, Duncan LA, Jacobsen EJ, McCall JM (1987) Novel 21-amino steroids as potent inhibitors of irondependent lipid peroxidation. J Biol Chem 262:10438-10440.

Brew H, Attwell D (1987) Electrogenic glutamate uptake is a major current carrier in the membrane of axolotl retinal glial cells. Nature 327:707-709.

Choi DW (1988) Glutamate neurotoxicity and diseases of the nervous system. Neuron 1:623-634.

Choi DW (1992) Bench to bedside: the glutamate connection. Science 258:241-243.

Cleland WW (1964) Dithiothreitol, a new protective reagent for $\mathrm{SH}$ groups. Biochemistry 3:480-485.

Davies JA, Delsignore ME, Lin SW (1987) Protein damage and degradation by oxygen radicals. II. Modification of amino acids. J Biol Chem 262:9902-9907.

Della Corte E, Stirpe F (1972) The regulation of rat liver xanthine oxidase: involvement of thiol groups in the conversion of the enzyme activity from dehydrogenase (type D) into oxidase (type $\mathrm{O}$ ) and purification of the enzyme. Biochem J 126:739-745.

Demopoulos HB, Flamm ES, Pietronigro DD, Seligman ML (1980) The free radical pathology and the microcirculation in the major central nervous system disorders. Acta Physiol Scand [Suppl] 492: 91-I19.

Demopoulos HB, Flamm ES, Seligman ML, Pietronigro DD, Tomasula $J$, DeCrescito V (1982) Further studies on free radical pathology in the major central nervous system disorders: effect of very high doses of methylprednisolone on the functional outcome, morphology and 
chemistry of experimental spinal cord impact injury. Can J Physiol Pharmacol 60:1415-1424.

Drejer J, Benveniste H, Diemer NH, Schousboe A (1985) Cellular origin of ischemia-induced glutamate release from brain tissue in vivo and in vitro. J Neurochem 45:145-151.

Dykens JA, Stern A, Trenkner E (1987) Mechanism of kainate toxicity to cerebellar neurons in vitro is analogous to reperfusion tissue injury. J Neurochem 49:1222-1228.

Faden AI, Demediuk P, Panter SS, Vink R (1989) The role of excitatory amino acids and NMDA receptors in traumatic brain injury. Science 244:798-800.

Fleming WW (1980) The electrogenic $\mathrm{Na}^{+}, \mathrm{K}^{+}$-pump in smooth muscle: physiologic and pharmacologic significance. Annu Rev Pharmacol Toxicol 20:129-149.

Hall ED, Braughler JM (1989) Central nervous system trauma and stroke. II. Physiological and pharmacological evidence for involvement of oxygen radicals and lipid peroxidation. Free Radical Biol Med 6:303-313.

Halliwell B (1987) Oxidants and human disease: some new concepts. FASEB J 1:358-364.

Halliwell B (1992) Reactive oxygen species and the central nervous system. J Neurochem 59:1609-1623.

Hauptman M, Nelson D, Wilson DF, Erecinska M (1984) Neurotransmitter amino acids in the CNS. II. Some changes in amino acid levels in rat brain synaptosomes during and after in vitro anoxia and simulated ischemia. Brain Res 304:23-35.

Hexum TD, Fried R (1979) Effects of superoxide radicals on transport $(\mathrm{Na}+\mathrm{K})$ adenosine triphosphatase and protection by superoxide dismutase. Neurochem Res 4:73-82.

Ikeda M, Nakazawa T, Abc K, Kancko T, Yamatsu K (1989) Extracellular accumulation of glutamate in the hippocampus induced by ischemia is not calcium dependent - in vitro and in vivo evidence. Neurosci Lett 96:202-206.

Johnson SW, Seutin V, North RA (1992) Burst firing in dopamine neurons by $N$-methyl-D-aspartate: role of electrogenic sodium pump. Science 258:665-667.

Katayama Y, Kawamata T, Tamura T, Hovda DA, Becker DP, Tsubokawa $T$ (1991) Calcium-dependent glutamate release concomitant with massive potassium flux during cerebral ischemia in vivo. Brain Res 558:136-140.

Koh JY, Choi DW (1987) Quantitative determination of glutamate mediated cortical neuronal injury in cell culture by lactate dehydrogenase efflux assay. J Neurosci Methods 20:83-90.

Lees VGJ (1993) Contributory mechanisms in the causation of neurodegenerative disorders. Neuroscience 54:287-322.

Lowry OH, Rosebrough NJ, Farr AL, Randall RJ (1951) Protein measurements with the Folin phenol reagent. J Biol Chem 193:265275.

McBean GJ, Roberts PJ (1985) Neurotoxicity of L-glutamate and DLthreo-3-hydroxyaspartate in the rat striatum. J Neurochem 44:247254.

McCarthy KD, de Vellis J (1980) Preparation of separate astroglial and oligodendroglial cell cultures from rat cerebral tissue. J Cell Biol 85:890-892.

McCord JM (1985) Oxygen-derived free radicals in postischemic tissue injury. N Engl J Med 312:159-163.

McGrail KM, Phillips JM, Sweadner J (1991) Immunofluorescent localization of three $\mathrm{Na}, \mathrm{K}$-ATPase isozymes in the rat central nervous system: both neurons and glia can express more than one $\mathrm{Na}, \mathrm{K}$ ATPase. J Neurosci 11:381-391.

Meister A, Anderson ME (1983) Glutathione. Annu Rev Biochem 52: 711-760.

Miyamoto M, Murphy TH, Schnaar RL, Coyle JT (1989) Antioxidants protect against glutamate-induced cytotoxicity in a neuronal cell line. J Pharmacol Exp Ther 250:1132-1140.

Monyer H, Hartley DM, Choi DW (1990) 21 -Aminosteroids attenuate excitotoxic neuronal injury in cortical cell cultures. Neuron 5:121126

Murphy TH, Miyamoto M, Sastre A, Schnaar RL, Coyle JT (1989)
Glutamate toxicity in a neuronal cell line involves inhibition of cystine transport leading to oxidative stress. Neuron 2:1547-1558.

Newman EA (1985) Voltage-dependent calcium and potassium channels in retinal glial cells. Nature 317:809-811.

Ogita K, Yoneda Y (1986) Characterization of $\mathrm{Na}^{+}$-dependent binding sites of $\left[{ }^{3} \mathrm{H}\right]$ glutamate in synaptic membranes from rat brain. Brain Res 397:137-144.

Oliver CN, Starke-Reed PE, Stadtman ER, Liu GJ, Carney JM, Floyd RA (1990) Oxidative damage to brain proteins, loss of glutamine synthetase activity, and production of free radicals during ischemia/ reperfusion-induced injury to gerbil brain. Proc Natl Acad Sci USA 87:5144-5147.

Orrenius S, McConkey DJ, Bellomo G, Nicotera P (1989) Role of $\mathrm{Ca}^{2+}$ in toxic cell killing. Trends Pharmacol Sci 10:281-285.

Pellegrini-Giampietro DE, Cherici G, Alesiani M, Carla V, Moroni F (1990) Excitatory amino acid release and free radical formation may cooperate in the genesis of ischemia-induced neuronal damage. J Neurosci 10:1035-1041.

Pines G, Danbolt NC, Bioras M, Zhang Y, Bendahan A, Eide L, Koepsell H, Storm-Mathisen J, Seeberg E, Kanner B (1992) Cloning and expression of a rat brain L-glutamate transporter. Nature 360:464467.

Rosen DR, Siddique T, Patterson D, Figlewicz DA, Sapp P, Hentati A Donaldson D, Goto J, O'Regan JP, Deng H-X, Rahmani Z, Krizus A, McKenna-Yasek D, Cayabyab A, Gaston SM, Berger R, Tanzi RE, Halperin JJ, Herzfeldt B, Van den Bergh R, Hung W-Y, Bird T, Deng G, Mulder DW, Smyth C., I aing NG, Soriano F, Pericak-Vance MA, Haines J, Rouleau GA, Gusella JS, Horvitz HR, Brown RH Jr (1993) Mutations in $\mathrm{Cu} / \mathrm{Zn}$ superoxide dismutase gene are associated with familial amyotrophic lateral sclerosis. Nature 362:59-62.

Rothman SM, Olney JW (1987) Excitotoxicity and the NMDA receptor. Trends Neurosci 10:299-302.

Rothstein JD, Martin LJ, Kunkl RW (1992) Decreased glutamate transport by the brain and spinal cord in amyotrophic lateral sclerosis. N Engl J Med 326:1464-1468.

Rubio I, Torres M, Miras-Portugal MT, Sànchez-Prieto J (1991) $\mathrm{Ca}^{2+}$ independent release of glutamate during in vitro anoxia in isolated nerve terminals. J Neurochem 57:1159-1164.

Siesjö BK, Agardh C-D, Bengtsson F (1989) Free radicals and brain damage. Cerebrovasc Brain Metab Rev 1:165-211.

Silverstein FS, Buchanan K, Johnston MV (1986) Perinatal hypoxiaischemia disrupts striatal high-affinity $\left[{ }^{3} \mathrm{H}\right]$ glutamate uptake into synaptosomes. J Neurochem 47:1614-1619.

Slater TF (1984) Free-radical mechanisms in tissue injury. Biochem J $222: 1-15$

Swanson RA (1992) Astrocyte glutamate uptake during chemical hypoxia in vitro. Neurosci Lett 147:143-146.

Sweadner KJ (1979) Two molecular forms of $\left(\mathrm{Na}^{+}+\mathrm{K}^{+}\right)$-stimulated ATPase in brain. J Biol Chem 254:6060-6067.

Urban L, Neill KH, Crain BJ, Nadler JV, Somjen GG (1989) Postischemic synaptic physiology in area CA1 of the gerbil hippocampus studied in vitro. J Neurosci 9:3966-3975.

Volterra A, Trotti D, Cassutti P, Tromba C, Salvaggio A, Melcangi RC, Racagni $G$ (1992) High sensitivity of glutamate uptake to extracellular free arachidonic acid levels in rat cortical synaptosomes and astrocytes. J Neurochem 59:600-606.

Weinberger J, Cohen G (1982) The differential effect of ischemia on the active uptake of dopamine, $\gamma$-aminobutyric acid, and glutamate by brain synaptosomes. J Neurochem 38:963-968.

Witting LA (1980) Vitamin E and lipid antioxidants in free-radicalinitiated reactions. In: Free radicals in biology, Vol 4 (Pryor WA, ed), pp 295-319. New York: Academic.

Wyllie DJA, Mathie A, Symonds CJ, Cull-Candy SG (1991) Activation of glutamate receptors and glutamate uptake in identified macroglial cells in rat cerebellar cultures. J Physiol (Lond) 432:235-258.

Yoshida S, Abe K, Busto R, Watson BD, Kogure K, Ginsberg MD (1982) Influence of transient ischemia on lipid-soluble antioxidants, free fatty acids and energy metabolism in rat brain. Brain Res 245 : 307-316. 